\title{
Risk factors of Pressure Ulcers in hospitalized elderly Egyptian people
}

Heba Mohamed Tawfik', Mohammed Mamdouh Mohammed ${ }^{2}$, Hala Samir Sweed ${ }^{1}$

1 Geriatrics and Gerontology Department, Faculty of Medicine, Ain Shams University, Cairo, Egypt.

2 Internal Medicine department, Health insurance organization, Ismailia, Egypt

\begin{abstract}
Background: Pressure ulcers affect a large scale of elderly people. Despite advances in technology, the rate continues to increase. This increases morbidity, health care costs and mortality.
\end{abstract}

Aim: searching for risk factors of pressure ulcers in elderly patients admitted to acute geriatric care units.

Methods: A case control study was conducted recruiting100 elderly male and female patients above the age of sixty. History and physical examination were done, as well as nutritional and functional assessment. Nursing care was assessed using a checklist and Braden scale was done as a risk assessment scale for pressure ulcers. Blood samples were collected for laboratory measures.

Results: pressure ulcers result from contribution of many factors as cardiovascular and cerebrovascular diseases, urinary incontinence, poor nutrition, immobility. Patients free from pressure ulcers had better nursing care with more frequent repositioning and use of air mattress (in more than $80 \%$, compared use of air mattress in about $40 \%$ only of patients acquiring pressure ulcers). Braden scale was highly sensitive for the occurrence of pressure ulcers (cutoff point $\leq 17$ ) with $77.4 \%$ positive predictive value and $97.3 \%$ negative predictive value.

Conclusion: Pressure ulcers are multifactorial in origin. Nursing care is of utmost importance for their prevention. Braden scale should be applied to elderly patients upon admission to hospital.

Keywords: Pressure ulcers - nursing-Braden scale- Egyptians

\section{Background}

Pressure ulcers (PUs) are increasing with aging of the population around the world and represent a common and frustrating problem affecting geriatric patients. Age-related skin changes increase the vulnerability to ulceration. Aging not only increases the risk of PU occurrence, but also affects healing of such ulcers. Also, frailty, associated comorbidities, impaired mobility, and cognitive impairment predispose many elderly populations to the development of PUs $(1,2)$. The prevalence of PUs peaks in those between age 70 and 80 years. They occur in hospitals, nursing homes, and even in community settings. The highest incidence of new ulcers occurs in hospitals and may be as high as $50 \%$ in acute care geriatric units, increasing health care expenditure and mortality rate, whereas the highest prevalence occurs in long-term care facilities (3). Also, the incidence of ulcers differs by the stage of ulceration. Stage 1 and 2 occur more frequently than later stages (4). Despite the progress in technology and medical advances, the cost of management of hospital acquired PU is increasing. The cost of treating these mainly preventable ulcers in the United Kingdom (UK) accounts for about $4 \%$ of the total National Health
Service (NHS) expenditure (5). Therefore, the identification of people at risk for PUs is an important component of preventive care for the elderly (6). The National Pressure Ulcer Advisory Panel (NPUAP) has agreed that not all PUs are preventable and there are clinical situations in which the development of PUs can be unavoidable such as end stage dementia, severe congestive heart failure and forced immobilization (7). To our knowledge only few studies were done in Egypt, approaching mainly nurses' knowledge and educational programs about PU and no studies searched for risk factors for PU in Egyptian population $(8,9,10)$.

\section{Methods}

A case control study, recruiting 100 male and female elderly patients aged $\geq 60$ years old from acute geriatric care units. The study was conducted in Ain Shams University Hospitals and in Suez Canal University Hospitals. It was designed to study risk factors for the occurrence of PUs in hospitalized elderly Egyptian patients. After assessment and follow up, all Patients were divided according to the presence or absence of pressure ulcers into cases (Group A) which included 50 
elderly patients who developed pressure ulcers and controls (Group B) which included 50 elderly patients without pressure ulcers matched for age and sex. Informed consent was taken from the patient or care giver after explanation of the study's aim and procedures. Patients or caregiver who refused to participate were excluded from the study. Follow up of the patients was done till discharge and the development of PUs was recorded. To assess risk factors for pressure ulcers, all participants were subjected to full medical history and physical examination, with special concern to daily skin examination. Functional status of the patients was assessed by the ability of the patient to perform activities of daily living (ADL) scale (11). Basic activities of daily living includes the following basic tasks (e.g. bathing- dressing- toileting- transfer continence and feeding). Nutritional assessment was done by Mini Nutritional Assessment scale (12), the Arabic version (13). It is a validated nutritional screening and assessment tool that can identify geriatric patients who are malnourished or at risk of malnutrition. Assessment of nursing care was done through a checklist that included four items: daily initial and reassessment of skin, the use of lifting devices to help move and reposition of patients, the use of pressure reducing mattress bed and the use of pillows or foam wedges to keep bony prominences away from direct contact with each other (14). Braden scale was used as a risk assessment scale and performed within 24 hours of hospital admission. It is widely used, sensitive and specific and consists of six subcategories assessing sensory perception, moisture, activity, mobility, nutrition and friction/shear. The total score ranges from 6-23, with lower values indicating higher risk for PUs (15). Blood samples were collected to measure kidney functions, electrolytes, blood count and proteins.

\section{Statistical Analysis}

The statistical analysis was carried out with the Statistical Package for the Social Sciences for Windows version 16.0 (SPSS Inc., Chicago, IL, USA.). Description of data in the form of mean (M) and standard deviation (SD) for all quantitative variables and frequency and percentage for all qualitative variables. Comparison of qualitative variables was done using chi-square test (X2). Significance levels measured according to $\mathrm{P}$ value (probability) $\mathrm{P}>0.05$ insignificant, $\quad \mathrm{P}<0.05$ significant, $\quad \mathrm{P}<0.01$ highly significant. Sensitivity, specificity, positive and negative predictive values for cutoff point were calculated Braden scale. ROC curve was conducted to determine Braden scale cut off point.

\section{Results}

The study included 59 male and 41 female elderly patients. Mean age was 68.92 in cases and 66.18 in controls as shown in Table 1. Illiteracy was more prevalent in patients with PUs (p 0.033). About $25 \%$ of cases and $50 \%$ of controls were non-smokers. There was no significant difference between both groups regarding sex, age, smoking and socioeconomic status. Cardiovascular diseases, hypertension, cerebrovascular stroke, dementia, fractures and urinary incontinence were more prevalent in cases than controls, whereas diabetes mellitus, chronic kidney disease (CKD) and chronic obstructive lung diseases (COPD) showed no statistical differences between cases and controls. PUs significantly increased the length of hospital stay. As shown in Table 2, there was a great difference in function between patients with and without PUs, with more dependency in daily activities in cases ( $p<0.001)$ for all items of ADL scale. Only one patient with PUs had adequate nutrition and the rest were either malnourished or at risk of malnutrition, in contrast to controls in which $48 \%$ had adequate nutrition (p $<0.001)$. Checklist for nursing care in Table 3 showed that the use of air mattress beds, pillows and foam and frequent reposition of the patients were more in control group; without PUs $(\mathrm{p}<0.001)$ for all. Table 4 showed that the mean Braden scale was 10.66 in cases and 18.82 in controls ( $\mathrm{p}<0.001$ ). ROC curve showed that score $\leq 17$ in the Braden scale had $97.96 \%$ sensitivity, $72 \%$ specificity, $77.4 \%$ positive predictive value (PPV) and $97.3 \%$ negative predictive value (NPV) for predicting PUs. Comparing laboratory results in Table 5, Total proteins, albumin and $\mathrm{Mg}$ levels were significantly lower in cases $(\mathrm{p} \leq 0.001,0.032, \leq 0.001)$ respectively, whereas total leukocytes count and creatinine levels were higher (p 0.004, 0.010) respectively.

\section{Discussion}

Many studies were performed to determine risk factors for PU development, but only few studies were targeted to identify risk factors among elderly people who are more likely to develop PUs than others. About $34 \%$ of patients having PUs had heart disease (including heart failure and ischemic heart disease) and $76 \%$ had hypertension. Also30\% of cases had either recent or old cerebrovascular stroke. This agrees with a study done in America, relating cardiovascular and cerebrovascular diseases to PU occurrence (16). Urinary incontinence is of utmost importance, increasing PU risk. In a systemic review done in 2013, moisture from either urinary or stool incontinence was studied in more than 27 studies, about 14 studies found that moisture significantly increased PU risk (17). 
Table 1: Demography and clinical characteristics of the study population.

\begin{tabular}{|c|c|c|c|c|c|c|}
\hline & \multicolumn{2}{|c|}{$\begin{array}{c}\text { Group A } \\
\text { Patients having PUs (cases) } \\
\text { Number }=\mathbf{5 0}\end{array}$} & \multicolumn{2}{|c|}{$\begin{array}{c}\text { Group B } \\
\text { Patients with no PUs } \\
\text { (controls) } \\
\text { Number }=\mathbf{5 0}\end{array}$} & \multicolumn{2}{|c|}{ Chi-square test } \\
\hline & No. & $\%$ & No. & $\%$ & $\mathbf{x 2}$ & p-value \\
\hline \multicolumn{7}{|l|}{ Sex } \\
\hline Male & 30 & $60.0 \%$ & 29 & $58.0 \%$ & \multirow[t]{2}{*}{0.041} & \multirow[t]{2}{*}{0.839} \\
\hline Female & 20 & $40.0 \%$ & 21 & $42.0 \%$ & & \\
\hline \multicolumn{7}{|l|}{ Age } \\
\hline Mean \pm SD & \multicolumn{2}{|c|}{$68.92 \pm 6.01$} & \multicolumn{2}{|c|}{$66.18 \pm 3.92$} & \multirow[t]{2}{*}{1.800} & \multirow[t]{2}{*}{0.061} \\
\hline Range & \multicolumn{2}{|c|}{$60-84$} & \multicolumn{2}{|c|}{$60-76$} & & \\
\hline \multicolumn{7}{|l|}{ Education } \\
\hline Illiterate & 38 & $76.0 \%$ & 26 & $52.0 \%$ & \multirow[t]{4}{*}{8.747} & \multirow[t]{4}{*}{0.033} \\
\hline Primary school & 11 & $22.0 \%$ & 16 & $32.0 \%$ & & \\
\hline Prep. school & 1 & $2.0 \%$ & 6 & $12.0 \%$ & & \\
\hline High school & $\mathbf{0}$ & $0.0 \%$ & 2 & $4.0 \%$ & & \\
\hline \multicolumn{7}{|l|}{ Smoking } \\
\hline Smoker & 12 & $24.0 \%$ & 18 & $36.0 \%$ & \multirow[t]{3}{*}{3.000} & \multirow[t]{3}{*}{0.223} \\
\hline Non smoker & 25 & $50.0 \%$ & 25 & $50.0 \%$ & & \\
\hline Ex-smoker & 13 & $26.0 \%$ & 7 & $14.0 \%$ & & \\
\hline \multicolumn{7}{|l|}{ Socio-economic } \\
\hline Low & 7 & $14.0 \%$ & 3 & $6.0 \%$ & \multirow[t]{2}{*}{1.778} & \multirow[t]{2}{*}{0.182} \\
\hline Average & 43 & $86.0 \%$ & 47 & $94.0 \%$ & & \\
\hline & \multicolumn{5}{|c|}{ Heart Disease } & 0.019 \\
\hline Hypertension & 38 & $76.0 \%$ & 26 & $52.0 \%$ & 6.250 & 0.012 \\
\hline Diabetes Mellitus & 23 & $46.0 \%$ & 24 & $48.0 \%$ & 0.040 & 0.841 \\
\hline Liver disease & 14 & $28.0 \%$ & 15 & $30.0 \%$ & 0.049 & 0.826 \\
\hline Stroke & 15 & $30.0 \%$ & 1 & $2.0 \%$ & 14.583 & $<0.001$ \\
\hline Dementia & 10 & $20.0 \%$ & 1 & $2.0 \%$ & 8.274 & 0.004 \\
\hline Falls & 3 & $6.0 \%$ & 1 & $2.0 \%$ & 1.042 & 0.307 \\
\hline Fractures & 12 & $24.0 \%$ & 3 & $6.0 \%$ & 6.353 & 0.012 \\
\hline COPD & 5 & $10.0 \%$ & 7 & $14.0 \%$ & 0.379 & 0.538 \\
\hline CKD & 8 & $16.0 \%$ & 3 & $6.0 \%$ & 2.554 & 0.110 \\
\hline Urinary incontinence & 11 & $22.0 \%$ & 3 & $6.0 \%$ & 5.316 & 0.021 \\
\hline $\begin{array}{c}\text { Length of hospital stay } \\
\text { Mean } \pm \text { SD }\end{array}$ & \multicolumn{2}{|c|}{$6.60 \pm 2.63$} & \multicolumn{2}{|c|}{$3.64 \pm 1.45$} & \multirow[t]{2}{*}{14.857} & \multirow[t]{2}{*}{$<0.001$} \\
\hline Range & & & & & & \\
\hline
\end{tabular}


Table 2: Comparison between group A and group B regarding activities of daily living (ADL) and Mini-nutritional assessment.

\begin{tabular}{|c|c|c|c|c|c|c|}
\hline & \multicolumn{2}{|c|}{$\begin{array}{c}\text { Group A } \\
\text { Cases }\end{array}$} & \multicolumn{2}{|c|}{$\begin{array}{l}\text { Group B } \\
\text { Controls }\end{array}$} & \multirow{2}{*}{$\begin{array}{c}\text { Chi-square } \\
\text { test } \\
\mathbf{x} 2 \\
\end{array}$} & \multirow[b]{2}{*}{ p-value } \\
\hline & No. & $\%$ & No. & $\%$ & & \\
\hline \multicolumn{7}{|l|}{ Bathing } \\
\hline Independent & $\mathbf{0}$ & $0.0 \%$ & 21 & $42.0 \%$ & \multirow[t]{3}{*}{41.308} & \multirow[t]{3}{*}{$<0.001$} \\
\hline Assisted & 9 & $18.0 \%$ & 18 & $36.0 \%$ & & \\
\hline Dependent & 41 & $82.0 \%$ & 11 & $22.0 \%$ & & \\
\hline \multicolumn{7}{|l|}{ Dressing } \\
\hline Independent & 0 & $0.0 \%$ & 29 & $58.0 \%$ & \multirow[t]{3}{*}{46.855} & \multirow[t]{3}{*}{$<0.001$} \\
\hline Assisted & 14 & $28.0 \%$ & 13 & $26.0 \%$ & & \\
\hline Dependent & 36 & $72.0 \%$ & 8 & $16.0 \%$ & & \\
\hline \multicolumn{7}{|l|}{ Toileting } \\
\hline Independent & $\mathbf{0}$ & $0.0 \%$ & 22 & $44.0 \%$ & \multirow[t]{3}{*}{38.966} & \multirow[t]{3}{*}{$<0.001$} \\
\hline Assisted & 11 & $22.0 \%$ & 17 & $34.0 \%$ & & \\
\hline Dependent & 39 & $78.0 \%$ & 11 & $22.0 \%$ & & \\
\hline \multicolumn{7}{|l|}{ Transfer } \\
\hline Independent & 0 & $0.0 \%$ & 21 & $42.0 \%$ & \multirow[t]{3}{*}{38.370} & \multirow[t]{3}{*}{$<0.001$} \\
\hline Assisted & 11 & $22.0 \%$ & 18 & $36.0 \%$ & & \\
\hline Dependent & 39 & $78.0 \%$ & 11 & $22.0 \%$ & & \\
\hline \multicolumn{7}{|l|}{ Continence } \\
\hline Independent & 0 & $0.0 \%$ & 23 & $46.0 \%$ & \multirow[t]{3}{*}{40.850} & \multirow[t]{3}{*}{$<0.001$} \\
\hline Assisted & 13 & $26.0 \%$ & 18 & $36.0 \%$ & & \\
\hline Dependent & 37 & $74.0 \%$ & 9 & $18.0 \%$ & & \\
\hline \multicolumn{7}{|l|}{ Feeding } \\
\hline Independent & 11 & $22.0 \%$ & 36 & $72.0 \%$ & \multirow[t]{3}{*}{35.143} & \multirow[t]{3}{*}{$<0.001$} \\
\hline Assisted & 4 & $8.0 \%$ & 8 & $16.0 \%$ & & \\
\hline Dependent & 35 & $70.0 \%$ & 6 & $12.0 \%$ & & \\
\hline $\begin{array}{l}\text { Mini-Nutritional assessment } \\
\text { score }\end{array}$ & 1 & $2.0 \%$ & 24 & $48.0 \%$ & \multirow{4}{*}{33.429} & \multirow{4}{*}{$<0.001$} \\
\hline normal(24-30 points) & & & & & & \\
\hline $\begin{array}{c}\text { at risk of malnutrition (17-23.5 } \\
\text { points) }\end{array}$ & 36 & $72.0 \%$ & 25 & $50.0 \%$ & & \\
\hline malnourished(<17points) & 13 & $26.0 \%$ & 1 & $2.0 \%$ & & \\
\hline
\end{tabular}

Table 3: Nursing care in patients with and without pressure ulcers.

\begin{tabular}{|c|c|c|c|c|c|c|}
\hline & No. (50) & $\%$ & No. (50) & $\%$ & $\mathbf{x 2}$ & p-value \\
\hline Using lifting devices & 1 & $2.0 \%$ & 0 & $\mathbf{0 . 0 \%}$ & 1.010 & 0.315 \\
\hline Using air mattress beds & 20 & $40.0 \%$ & 43 & $86.0 \%$ & 20.482 & $<0.001$ \\
\hline Using pillows or foams & 11 & $22.0 \%$ & 39 & $78.0 \%$ & 47.868 & $<0.001$ \\
\hline Frequent reposition of the patient & 10 & $20.0 \%$ & 43 & $86.0 \%$ & 25.010 & $<0.001$ \\
\hline
\end{tabular}

Table (4): Braden scale score in Group A and B and Receiver operating characteristics (ROC) curve for Braden scale cutoff value

\begin{tabular}{|c|c|c|c|c|c|}
\hline Brade & le score & Group A & Group B & t-test & p-value \\
\hline & & $10.66 \pm 3.15$ & $18.82 \pm 4.06$ & 125.817 & $<0.001$ \\
\hline Cut-off. & Sensitivity & Specificity & PPV & NPV & Accuracy \\
\hline
\end{tabular}


Figure 1: Receiver operating characteristics (ROC) curve for Braden scale cutoff value

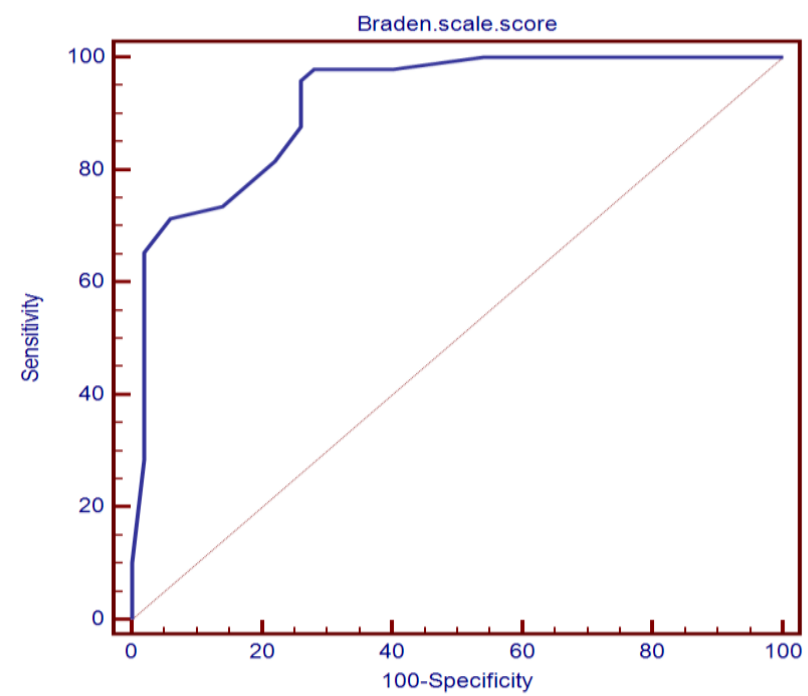

Table (5): Laboratory data in Group A and Group B

\begin{tabular}{|c|c|c|c|c|}
\hline & Group A & Group B & t-test & p-value \\
\hline \multicolumn{5}{|l|}{ Hemoglobin } \\
\hline Mean \pm SD & $11.11 \pm 1.52$ & $11.74 \pm 2.26$ & \multirow[t]{2}{*}{2.681} & \multirow[t]{2}{*}{0.105} \\
\hline Range & 7-14.2 & 7.6-15.7 & & \\
\hline \multicolumn{5}{|c|}{ Total leukocytic count } \\
\hline Mean \pm SD & $12.25 \pm 6.08$ & $9.10 \pm 4.60$ & \multirow[t]{2}{*}{8.532} & \multirow[t]{2}{*}{0.004} \\
\hline Range & 3.3-31 & 2.9-21.8 & & \\
\hline \multicolumn{5}{|l|}{ Platelet count } \\
\hline Mean \pm SD & $234.78 \pm 88.32$ & $246.34 \pm 103.14$ & \multirow[t]{2}{*}{0.362} & \multirow[t]{2}{*}{0.549} \\
\hline Range & $67-401$ & $6-568$ & & \\
\hline \multicolumn{5}{|l|}{ Total proteins } \\
\hline Mean \pm SD & $5.00 \pm 0.60$ & $6.51 \pm 1.02$ & \multirow[t]{2}{*}{12.870} & \multirow[t]{2}{*}{$<0.001$} \\
\hline Range & 4.1-6.1 & 4.4-8.1 & & \\
\hline \multicolumn{5}{|l|}{ Albumin } \\
\hline Mean \pm SD & $2.46 \pm 0.62$ & $3.52 \pm 1.2$ & \multirow[t]{2}{*}{3.762} & \multirow[t]{2}{*}{0.032} \\
\hline Range & $1.5-3.6$ & $1.9-4.9$ & & \\
\hline \multicolumn{5}{|l|}{$\mathrm{Na}$} \\
\hline Mean \pm SD & $135.02 \pm 5.14$ & $133.87 \pm 19.22$ & \multirow[t]{2}{*}{0.168} & \multirow[t]{2}{*}{0.683} \\
\hline Range & 125-158 & 5.4-149 & & \\
\hline \multicolumn{5}{|l|}{$\mathbf{K}$} \\
\hline Mean \pm SD & $3.81 \pm 0.50$ & $3.71 \pm 0.59$ & \multirow[t]{2}{*}{0.701} & \multirow[t]{2}{*}{0.404} \\
\hline Range & 2.8-5.1 & $1.6-5.4$ & & \\
\hline \multicolumn{5}{|l|}{ Mg } \\
\hline Mean \pm SD & $1.66 \pm 0.23$ & $1.84 \pm 0.21$ & \multirow[t]{2}{*}{17.712} & \multirow[t]{2}{*}{$<0.001$} \\
\hline Range & 1.2-2.1 & $1.5-2.2$ & & \\
\hline \multicolumn{5}{|c|}{ Serum creatinine } \\
\hline Mean \pm SD & $1.60 \pm 0.93$ & $1.13 \pm 0.87$ & \multirow[t]{2}{*}{6.848} & \multirow[t]{2}{*}{0.010} \\
\hline Range & $0.6-4.9$ & 0.5-6 & & \\
\hline \multicolumn{5}{|l|}{ HbA1c } \\
\hline Mean \pm SD & $8.19 \pm 0.99$ & $7.82 \pm 0.86$ & \multirow[t]{2}{*}{1.709} & \multirow[t]{2}{*}{0.198} \\
\hline Range & 6.8-11 & $6.6-10.7$ & & \\
\hline
\end{tabular}


Urinary incontinence increases PU risk by more than one mechanism. Urine changes the skin $\mathrm{PH}$, which become predisposed to heavy bacterial load, leading to dermatitis and breakdown of the skin surface (18). Also, urine as well as sweat increases moisture, so the skin becomes more vulnerable to the effect of friction and shear forces (well known risk factors also) which weakens the dermis; which is considered a picture of microclimate (19). Nutrition has a vital role in PU prevention. Malnutrition was strongly associated with ulcer development as shown in many studies $(20,21)$. The appearance of pressure ulcers reflects a catabolic state accompanied by protein malnutrition and low consumption, resulting in muscle wasting and skin destruction (22). Regarding Nursing care, the use of pressure-reducing support surfaces (air mattress beds) had a vital role in prevention or reduction of the incidence of PUs among the hospitalized patients, especially elderly patients in acute care units. More than $85 \%$ of patients without PUs were using air mattress, while it was the case only in $40 \%$ of patients with PUs. Pressure relieving support surfaces are designed to prevent occurrence or promote the healing of PUs by reducing or eliminating tissue interface pressure applied on tissues for longtime. However, they represent one part of an overall system of care which must be implemented to reduce the risk of pressure associated tissue damage (23). Frequent repositioning of the patients had a great role in PU prevention with a big difference in nursing care between our cases and controls; may be due to patients' factors like uncooperative or agitated patients or nursing problems like deficiency of their numbers or more workload sometimes. These results are in agreement with the systemic review done in 2014 about the effect of repositioning in prevention of PUs, highlighting the great role of nurses in prevention of PUs and the importance of nurse' education in this issue (24). The mean score for Braden Scale in the study was much lower in patients with PUs, [10.66 (SD, 3.15) in cases and 18.82 (SD, 4.06) in controls, $\mathrm{P}<0.001]$. This ensures that the Braden scale is a good predictor for PU occurrence, as lower Braden scores indicate higher risk of developing a PU. Coleman et al., 2013 reported in their systemic review that overall, 22 studies out of 54 included a total score of risk assessment scales in their analysis and in 10 studies the total score emerged as statistically significant for prediction of PU (17). The Braden Scale cut-off point was $\leq 17$ in the study, with sensitivity of $97.96 \%$, specificity of $72 \%$, PPV of $77.4 \%$, and NPV of $97.3 \%$ with diagnostic accuracy of $92.1 \%$ for the occurrence of PUs. These results are in agreement with a retrospective study examining patients admitted to Englewood Hospital and Medical Center, in which mean Braden Scale scores also were statistically lower with patients with PUs. At a cut-off score of 18 , the sensitivity was $100 \%$, specificity was $71 \%$, positive predictive value was $20 \%$, and negative predictive value was $100 \%$ (25). Biochemical data analysis is one component of the comprehensive nutrition assessment process. Serum albumin and total protein levels were measured as a part of nutritional evaluation. As shown in a previous study, there is a relation between level of total proteins, serum albumin and occurrence of PUs (P-value <0.001, 0.032) respectively (2). Higher white blood cell (WBC) count in the study increased the risk of PU. This is in agreement with surveys on risk factors associated with PUs. Pieper et al., 1998 reported that older age, prolonged hospital stays, multiple co-morbidities, anemia, decreased serum albumin, increased WBC, and low Braden scores to be risk factors for PUs (26). However, leukocytosis occurs in many inflammatory conditions and in infection, so it is difficult to depend on it alone as a predictor of PUs. A significant correlation was found between magnesium levels, PU development. Hypomagnesaemia can lead to the induction of proinflammatory response, increased oxidative stress and apoptosis. It was found that hypomagnesaemia in diabetic patients was associated with poorer glycemic control, foot ulcers and impaired wound healing (27). As found in a previous study (28), the development of PU increased the length of hospital stay. The presence of PU had prolonged the hospital stay in cases by about 5 or 6 days. This represents a burden increasing healthcare costs.

\section{Conclusion}

There is no single risk factor for PU occurrence. Urinary incontinence, nutritional and functional status are important predictors of PUs. Nursing care is of utmost importance for PU prevention. Braden scale should be applied to elderly patients upon admission to hospital.

\section{Acknowledgement}

All authors contributed to this work. There is no conflict of interest.

\section{References}

1. The National Institute for Health and Care Excellence (NICE), 2005.

2. Jaul E. Cohort study of atypical pressure ulcer development. Int Wound J.2014;11(6):696-700.

3. Kottner J, Tannen A, Dassen T. Hospital pressure ulcer prevalence rates and number of raters. J Clin. Nurs. 2009; 18(11): 1550-1556.

4. Lyder $\mathrm{CH}$, Ayello EA. The CMS pressure ulcer present-onadmission indicator. Adv Skin Wound Care. 2009;22(10): 476484.

5. Cooper K .Evidence based prevention of pressure ulcers in the Intensive Care Unit. Crit Care Nurse. 2013; 33(6):57-66.

6. Reddy M, Gill SS and Rochon PA. Preventing pressure ulcers: a systematic review. JAMA.2006; 296:974- 984.

7. Edsberg LE, Langemo D, Baharestani MM, Posthauer ME, Goldberg M. Unavoidable pressure injury: State of the science and consensus outcomes. J WOCN. 2014; 41(4): 313-334.

8. El-Sayed.,Mohamed Z.A.E, Mohamed Y.W. and El-Sonbaty A.M. Impact of in service training program on bed sores identification prevention and management among immobilized patients. Ass. Univ. Bull. Environ. Res.2003; 6(1): 133-145.

9. Mohamed SA and Weheida SM .Effects of implementing educational program about pressure ulcer control on nurses' 
knowledge and safety of immobilized patients. Jnep. 2015; 5(3).

10. El Enein NY and Zaghloul AA. Nurses' knowledge of prevention and management of pressure ulcer at a health insurance hospital in Alexandria. Int J Nurs Pract.2011;17(3):262-8.

11. Katz S, Ford $A B$ and Moswowitz RW. Studies of illness in the aged the index of ADL: Standardized measure of biological and psychological function, JA.A. 1963; 185-914.

12. Vellas B, Villars $H$, Abellan $G$, et al. Overview of the MNA $₫$ Its History and Challenges. J Nutr Health Aging.2006; 10:456465.

13. Abd-Al-Atty MF, Abou-Hashem RM, Abd Elaziz KM, et al. Test Your Memory test, Arabic version: is it practical in a different culture? J Am Geriatr Soc. 2012; 60: 596-597.

14. Lyder C, van Rijswijk L. Pressure ulcer prevention and care: preventing and managing pressure ulcers in long-term care: an overview of the revised federal regulation. Ostomy Wound Manage. 2005 Apr;Suppl:2-6.

15. Braden BJ, Bergstrom N, Laguzza A, Holman V. The Braden Scale for Predicting Pressure Sore Risk. Nurs Res. 1987; 36:205-210.

16. Cox J. Predictors of pressure ulcers in adult critical care patients. Am J Crit Care.2011; 20(5):364-375.

17. Coleman S., Gorecki C., Nelson E.A., Close S.J., Defloor T., Halfens R., Farrin A., Brown J., Schoonhoven L. \& Nixon J. Patient risk factors for pressure ulcer development: systematic review. Int J Nurs Stud. 2013; 50(7): 974-1003.

18. Errsser SJ, Getliffe K,Voegeli D, Regan S.A critical review of the inter-relationship between skin vulnerability and urinary incontinence and related nursing intervention. International Journal of Nursing Studies.2005; 2: 823-835.

19. Clark M, Romanelli M, Reger SI, Ranganathan VK, Black J, Dealey C. Microclimate in context. In: International review: pressure ulcer prevention: pressure, shear, friction and microclimate. A consensus document. London: Wounds International, 2010.

20. lizaka S, Okuwa M, Sugama J, Sanada H. The impact of malnutrition and nutrition-related factors on the development and severity of pressure ulcers in older patients receiving home care. Clin Nutr. 2010; $29: 47-53$.

21. Pinchcofsky-Devin GD, Kaminiski NW. Correlation of pressure sores and nutritional status. J Am Geriatric 1986; 34: 435-40.

22. Manley MT. Incidence, contributory factors, and costs of pressure sores. S Afr Med J 1978; 53 (6): 217-22.

23. Han PY, Ezquerro R. Surgical treatment of pressure ulcers of the heel in skilled nursing facilities: a 12-year retrospective study of 57 patients. J Am Podiatr Med Assoc. Mar- Apr 2011; 101(2):167-75.

24. Gillespie BM, Chaboyer WP, Mclnnes E, Kent B, Whitty JA, Thalib L. Repositioning for pressure ulcer prevention in adults. Cochrane Database Syst Rev. 2014 Apr 3;(4):CD009958.

25. Krapfl L, Mackey D. Medicare changes to the hospital inpatient prospective payment systems: commentary on the implications for the hospital-based wound care clinician. J Wound Ostomy Continence Nurs.2008;35(1):61-62.

26. Pieper B, Sugrue M, Weiland M, Sprague K, Heiman C. Risk Factors, Prevention Methods, and Wound Care for Patients With Pressure Ulcers. Clin Nurse Spec. 1998 Jan; 12(1):7-12; quiz 13-4.

27. Limaye CS, Londhey VA, Nadkar MY, Borges NE . Hypomagnesemia in critically ill medical patients. J Assoc $P$ hysicians India. 2011; $59: 19-22$.

28. Graves N, Birrell F, Whitby M. Infect Control Hosp Epidemiol. Mar 2005; 26(3):293-7. 